\title{
21104 手術用ねじの締め付け力測定機の開発
}

Development of Testing Machine for the Measurement of Binding Force of Surgical Screw

$\begin{array}{cllll}\text { O学 田村 } & \text { 敏教 (日本工大院) } & \text { 正 } & \text { 玉木 } & \text { 保 (日本工大) } \\ \text { 高橋 } & \text { 和久 (千葉大医) } & \text { 赤澤 } & \text { 努 (千葉大医) }\end{array}$

Toshinori TAMURA, Student, Department of Mechanical Engineering, Nippon Institute of Technology, 4-1 Gakuendai, Miyasiro, Minamisaitama, Saitama 345-8501 Japan

Tamotsu TAMAKI, Nippon Institute of Technology,

Kazuhisa TAKAHASHI, Tsutomu AKAZAWA, School of Medicine, Chiba University

For the operations of spinal deformity fixation, surgical screws are used. Studies of the relation between screw shape and the binding force are not reported so much. This paper investigated that relation of the screw in the market and binding force. The development of testing machine to measure binding force of the screw are investigated. the developed attachment for the screw is D $36 \mathrm{~mm} \times \mathrm{L} 58 \mathrm{~mm}$.

Key Words : Binding Force, Surgical Screw

\section{1.はじめに}

春柱側弯症や春柱損傷の治療方法として春柱固定用ねじ を用いた手術が多く行なわれている。そして，その力学的 検討も多くの研究者によって行なわれている。しかしねじ の形状によって骨にどのような影響を与えているかという ことは，まだあまり報告されていない，本研究室において は以前から, 実験用のねじ（以後, 実験用標準ねじと呼ぶ) を作製し, 専用の測定装置を使用してねじの締め付け力測 定試験を行ってきた。実験用標準対じとは，市販されてい る春柱固定用礼じの形状パラメータを参考にして平均的な 形状パラメータを算出し，それをもとに作製したものであ る. (Fig.1)

そこで本研究では，市販される春柱固定用ねじの形状が 骨にどのような影響を与えるかを，締め付け力を測定する ことにより調查することとした．そのために市販され，実 際に整形外科手術で使われている春柱固定用ねじの締め付 け力を簡便に測定するための測定機の設計について，特に 今回はアタッチメントについて検討を行った. 締め付け力 の測定センサーには E n t r a n 社製 ワッシャー型ロー ドセルを用い，測定值の記録には共和電業社製 $\mathrm{EDX}-1$

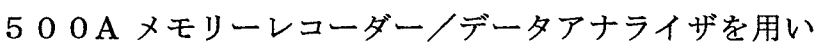
る.（Fig.2）本機械での測定方法を用いて得られるねじの 回転角々締め付け力との関係から，ねじの締め付け特性に ついても検討していく.

\section{2. 研究背景 1)}

市販の 7 種類のねじ (AO-Cortex、Zielke、Yamagata-A、 B,Danek-808、823 及び Pedicle）を参考にして実験用標隻 ねじを製作した。用いた試験機は島津オートグラフ DCS-500 材料試験機である. 被挿入材を下側治具（クロス ヘッド）に固定し，下穴をあけてタップをたててから上側 治具（ロードセルに固定）にねじを通し被挿入材にねじを 挿入する。そして自動ねじ挿入装置によりねじ挿入してい く.この時の試験機の測定荷重を締め付け力とした.

(Fig.3)

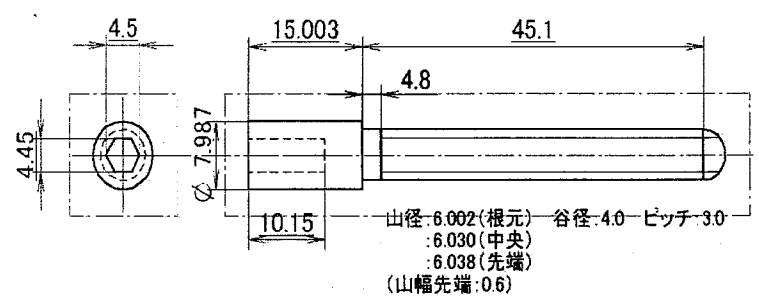

Fig.1 Screw with Long Wrench Hole for the Binding Force Experiment

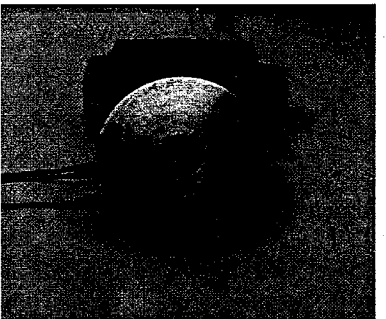

a) Washer Type Load Cell

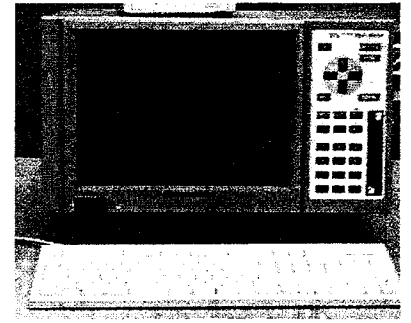

b) Memory Recorder / Data Analyzer
Fig.2 Measuring Device

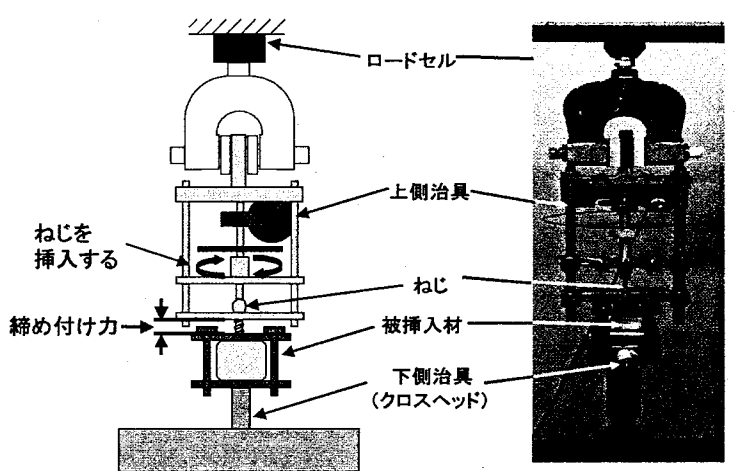

Fig.3 Binding Force Measurement by Material Testing Machine 


\section{3. 测定原理及び测定機器}

材料試験機を用いた測定方法では, 試験機に固定した上 側治具と下側治具の間に隙間を設け，ねじが挿入されてい くときに上側治具を引っ張る力を材料試験機のロードセル により測定していた．しかし，この方法では正確な測定が 行われているか疑問であり, 直感的でなくわかりにくい. そこで本研究では，ねじが締め込まれていく際にねじ頭と 被挿入材の閒に挟まれたリング型ロードセルを压縮する力 を締め付け力として測定する.（Fig.4）これにより以前ま での測定に比べ正確な測定が期待できる.

市販されている手術用ねじは頭穴が様々である。したが って，例えば頭穴が十字の場合，ねじを挿入していくとね じだけが下がり力を伝達できない，そこで，アタッチメン トを考案した。

（a）ねじとビットを収めるケース（以後，ねじ・ビット ケースと呼ぶ）に試験するねじとその頭穴に合わせたビッ トを入れ，ビットを固定するためのふた（以後，ビット押 さえと呼ぶ）をする。（b）モーター側からの力を伝達する 軸をビットの四角穴に入れる，以上が試験準備となる．(c) 試験を開始する。（d）ねじとアタッチメントが下がるがモ ーターからの力は伝達される。（Fig.5）

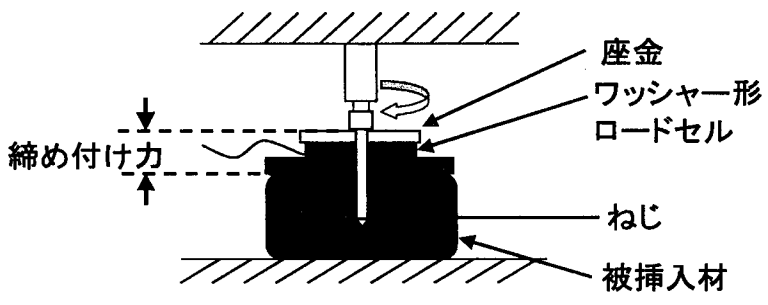

Fig.4 Scheme of Measurement

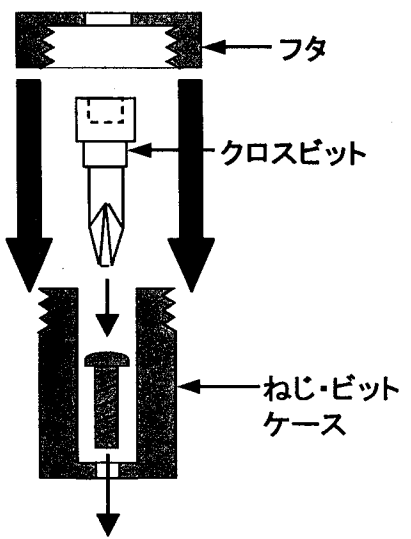

(a)

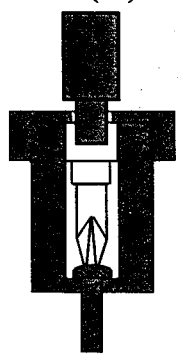

(c)

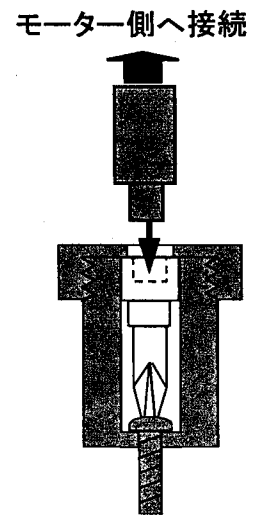

(b)

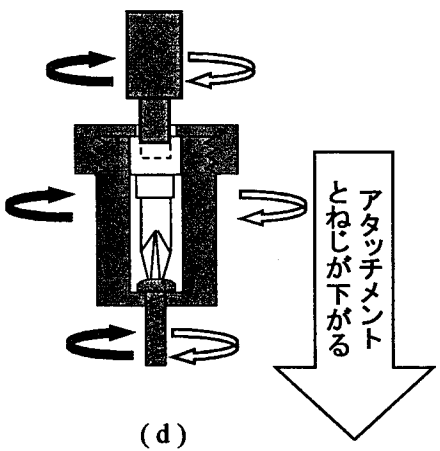

Fig.5 Mechanism of Driver Attachment

\section{4. 検討}

アタッチメントは製作中であるが，設計段階での寸法は $\mathrm{D} 36 \mathrm{~m} \mathrm{~m} \times \mathrm{L} 58 \mathrm{~mm}$ （最大寸法）である。また，円筒外周 面にローレット仕上げと二面取りを施し強固に固定できる ようにした. (Fig.6) アタッチメント用いることで，これ まで試験できなかったねじを試験することが可能となる. しかし緩めていくときのデータを採ることができないとい った改善点も考えられる.

ピッチ $3 \mathrm{~mm}$ の実験用標準ねじを用いてウシ腰椎骨に挿 入した際の，ねじの進入距離に対する締め付け力の関係を ワッシャータイプのロードセルで測定した.（Fig.7）この 例ではねじを約 $180^{\circ}$ 回転させ, $1.5 \mathrm{~mm}$ 挿入した時に最大 締め付け力 $1535 \mathrm{~N}$ が生じた。

$$
\text { 5.まとめ }
$$

ワッシャータイプのロードセルやアタッチメントの使用 により，簡単で正確な締め付け力試験が行えると考えられ る、今後はアタッチメントを完成させ，種々のねじについ て, 回転角と締め付け力の関係を調查していきたい。また 試験片については，模擬骨を使用する予定である。これは 海面骨にあたる部分がポリウレタンで，ち密骨にあたる部 分がガラス繊維を織り込んだエポキシ樹脂でつくられたも のである。

\section{参考文献}

（1） Nguyen Son，丸山公一，玉木保，高橋和久，山縣正 庸, 春柱固定用ねじの締め付け特性と挿入ねじ界面近 傍の骨構造、第 11 回バイオエンジニアリング講演会 秋季セミナー（新潟）一日本機械学会講演論文集 No00-26 p 159-160、2000.

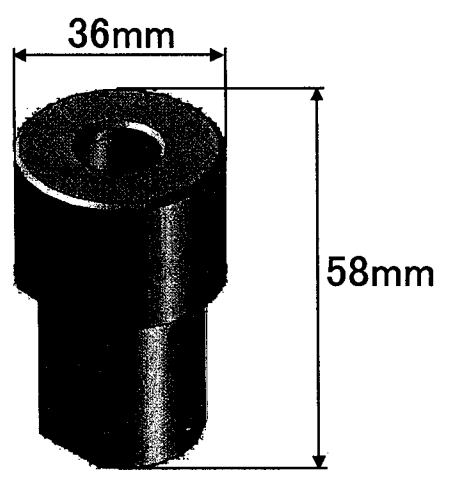

Fig.6 Maximum Parameter of Attachment

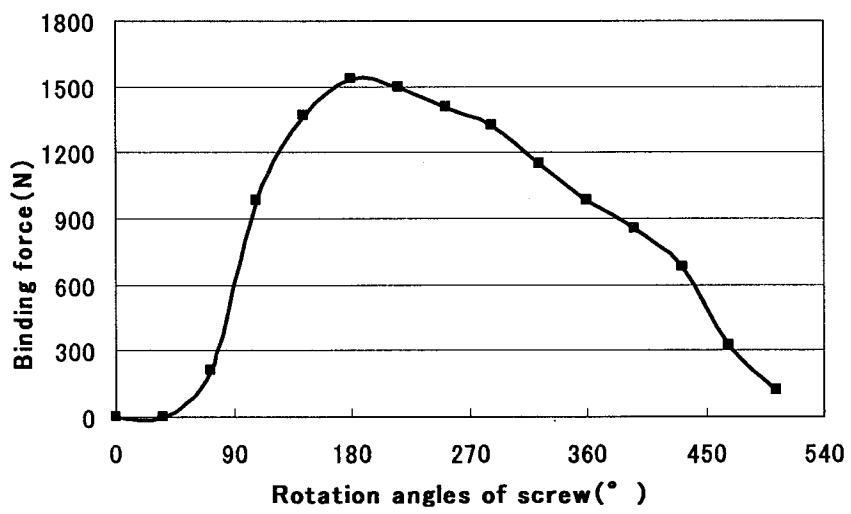

Fig. 7 Example of Binding Force to Screw Insertion $\left(120^{\circ}\right.$ Rotation per 1-mm Insertion) 